\title{
G8 - SUSPENSION OR FALL? FROM COLD WAR TO COLD WAR. A SHORT HISTORY OF RUSSIAN PARTICIPATION IN MAJOR INDUSTRIAL DEMOCRACIES
}

\begin{abstract}
As the result of Russian policy in Ukraine and annexation of the Crimea the G7 leaders agreed at the nuclear summit in the Hague on 25 March 2014, that instead of the G8 summit in Sochi in June 2014 there would be a meeting of G7 leaders in Brussels. These historic events concerning activities of the Group form the background for the specific research goals of this paper: to shortly present the reasons for establishing the G7 and G8; to briefly describe the various issues which have been discussed at annual summits; to introduce the multi-dimensional relations between the G7/G8 and other international organizations; and to assess the effectiveness of particular members of the Group in implementing the decisions taken at the summits. At the end of the paper an attempt is made to answer the question whether, in this new political situation, this specific international institution can continue to work actively for global security. One of the goals of this research was also to evaluate the activity of the G7/G8 from the perspective of more than 30 years. At the end of this paper I try to answer the question whether such a specific intergovernmental institution is still able to act effectively and influence the different dimensions of international security inherent in the new political situations, especially with respect to Russia's war-oriented foreign policy in 2014-2016.
\end{abstract}

Keywords: G7, G8, origin, system, international institutions, relations with Russia.

\section{INTRODUCTION}

On 12 March 122014 the leaders of Canada, France, Germany, Italy, Japan, the UK and the USA, as well as the Presidents of the European Council and European Commission, condemned the Russian Federation for its destabilizing actions, which resulted in a violation of Ukraine's sovereignty and territorial integrity. In a common statement they underscored that Russia violated the rules and values which the G7/G8 followed that time. As a result of Russia's policy, the leaders stopped preparation for G8 summit in Sochi in June 2014, postponing it until the correct conditions could appear for meaningful discussion in the same group ${ }^{2}$. This firm statement resulted in cancellation of a summit the first time in the G8's history. A week later German Chancellor Angela Merkel said that the current tensions with

1 Dr hab. Rafał Matera, prof. UŁ, associate professor, Faculty of Economics and Sociology, University of Lodz,paramat@wp.pl, rafal.matera@uni.lodz.pl

2 Official Website of the Prime Minister of Canada, http://www.pm.gc.ca/eng/news/2014/03/02/ statement-g-7-nations (14.06.2016). 
Russia meant that the G8 no longer exists ${ }^{3}$. The suspension of the G8 summit did not mean, however, that meetings within the G7 format would be discontinued. At the nuclear summit in the Hague on 25 March 2014, the G7 leaders agreed that instead of the G8 summit in Sochi in June 2014 there would be a meeting of G7 leaders in Brussels.

These historic events concerning activities of the Group form the background for the specific research goals of this paper: to shortly present the reasons for establishing the G7 and G8; to briefly describe the various issues which have been discussed at annual summits; to introduce the multi-dimensional relations between the G7/G8 and other international organizations; and to assess the effectiveness of particular members of the Group in implementing the decisions taken at the summits. At the end of the paper an attempt is made to answer the question whether, in this new political situation, this specific international institution $^{4}$ can continue to work actively for global security.

\section{THE REASONS FOR ESTABLISHING THE G7 AND G8}

The reasons underlying the creation of an organization of the most industrialized world states consisted of a combination of economic and political factors. The debates at the highest level were intensified by the difficulties in the world economy and energy problems. However, in order to counteract the economic difficulties it was also necessary to overcome political barriers, distrust among the leaders, and transatlantic discrepancies. This explains why the G7 summits constituted such great forums to debate the global situation and relations between world leaders, of both a political and economic scope.

Simultaneously with the diplomatic activities, intense discussions took place in the context of work in specialized groups and between ministries (especially finance ministers), both bilaterally and multilaterally. In the face of pressing monetary problems the finance ministers of the US, GFR, France, and the UK met periodically. The first meeting took place in the White House library in Washington in April 1973. The summits of finance ministers became known as the "Library Group". Later joined by Japan, the group met for a number of years and also came to be known as the Group of Five. The governors of the Central Banks of the G5 were also invited to these meetings ${ }^{5}$.

The final decision to organize the first meeting of the most industrialized powers was taken in Helsinki on 31 July 1975 during the Conference on Security and Cooperation in Europe. It was the initiative of President of France - Valery Giscard d'Estaing, who invited Chancellor Helmut Schmidt, US President Gerald Ford and the British and Japanese Prime Ministers. The Italian governmental representative was added at the last minute. The very first summit, with six states participating, was held in Rambouillet, France in 1975. The

3 On March 20, 2014, Chancellor Merkel said in the Bundestag: "As long as there is no political environment for such an important political format as the G8, the G8 doesn't exist anymore - neither the summit nor the format" (PAP, http://wiadomosci.gazeta.pl (14.06.2016).

4 Depending on the sphere of activity, such forums as the G7, G8 or G20 can be classified as multilateral political and economic institutions, having the features of operational institutions (i.e., those that affect the entire international environment) as well as normative institutions, which perpetuate the patterns of activity through the use of existing standards as well as the imposition of new ones (R. Matera, G8 jako instytucja gospodarki światowej, Łódź 2009, s. 90-94).

5 P. Hajnal, The G-7 Summit and Its Documents, "Government Information in Canada" [Electronic Journal], 1995, No. 3.3. 
name G7 became official in 1976 when Canadian participants joined the representatives of France, Germany, Great Britain, Italy, Japan and the US. Since the third meeting in 1977 (in London), the representatives of the Commission of European Communities became participants in the summit, albeit only as observers. Hence the name G7 stayed in place. However, the advantage of Europe over other members of the world was better seen after the addition of Russia to the G7.

Until the end of the Cold War there was no discussion about enlargement of the forum. However, beginning in 1989 the leaders of the G7 began to communicate with representatives of the Soviet Union (since 1992, Russia). The first visible contact took place in 1989 when president of the USSR Mikhail Gorbachev sent a letter to that year's summit host, the French President. At a press conference summing up the summit, Mitterrand said that the Soviet Union is a big country and plays an important role in the world, but stressed that the G7 countries adhere to democracy and have democratic institutions. He added: "If any of the countries would unfortunately depart from democracy, it would lose the opportunity to participate in the summit. But we see the evolution in the Soviet Union, although we are still not at the same level. Of course one day it can be possible. (...) At the beginning there were five of us, now seven. Too many countries could hinder the exchange of views, but this is not an obstacle to the prospect of extension"6. Mitterrand's words can be regarded as prophetic, as Russia was already a member of the new G8 at the time of its annexation of the Crimea and attempts to destabilize Ukraine in 2014.

In 1990 (the Houston Summit) the G7 supported having a representative of the USSR in political and economic reforms and called upon international organizations (IMF, IBRD) to compile a study of Eastern European economies. Boris Yeltsin, the first President of Russia, was periodically invited to the summits, but at the beginning he did not participate in all the meetings. Although he arrived at the summit in Tokyo in 1993, his meeting with the leaders of the G7 took part after the official closing of the summit. The meeting in Naples in July 1994 was a breakthrough in relations with Russia. For the first time the President of Russia was invited to participate in the political part of the meeting. And in in Naples for the first time one of the documents (a political declaration) was signed by the governments of eight countries. The Congress in Denver in June 1997 was called the 'Summit of the Eight', but not yet officially a G8. Representatives of the Moscow authorities participated on an equal footing in the political and economic discussions. However, the President of Russia did not sign a document concerning the G7's economic affairs.

The transformation into the G8 was formally made possible in 1998 during the Birmingham summit, after a few years of negotiations and common work in the forum along with Russia in the so-called 'G7 + Russia'. In the years following 1998, in particular when Russia was added to the political apparatus of the now expanded institution, it devoted its efforts mainly to winning debt reduction ${ }^{7}$. A historic decision was taken at the 2002 Kananaskis Summit, which closed the fourth cycle of the leaders' meetings, when Russia's full membership was adopted spontaneously (the issue was not on the agenda). This was largely

6 Press Conference of Mr. François Mitterrand, President of the French Republic, on the Conclusion of the Fifteenth Summit of Industrialized Countries, July 16, 1989, www.g7.utoronto.ca (10.09.2010).

7 M. Lin, A. Morson, J. Muravska, D. Verli, Russia and the G8. An Overview of Russia,s Integration into the G8, G8 Research Group, Toronto 2006, http://www.g7.utoronto.ca (12.11.2016). 
thanks to Chancellor Gerhard Schröder, who agreed to give way to Russia before the summit in Germany. The first congress of the G8 with Russia as host took place in St. Petersburg (Strelna) in 2006. The second summit organized by the Kremlin was the one supposed to take place in Sochi.

It should be noted that various economic and political factors were intertwined during the creation of the G8. The event that brought about Moscow's dialogue with the G7 was the collapse of the communist system and the beginning of systemic transformation. Russia was hoping for direct economic assistance. The West, in turn, wished to have an impact on the transformation process, as the predictability of changes would have a stabilizing effect on the capital market. An important role in the access of Russia to the G7 was played by the issue of disarmament, especially the reduction of nuclear forces. It was hard to imagine the improvement of global security without Moscow's involvement ${ }^{8}$.

\section{A BRIEF LOOK AT THE G7/G8 SYSTEM}

Due to the lack of an international agreement establishing the principles of the G7/G8's operation, they have undergone significant changes over time (especially in terms of expanded activities). Thus, one can speak of the development of a 'G7/G8 system'. It was initially based on leaders' summits, but over the years was supplemented by new forms of cooperation and the emergence of various new instruments which were used by the forum participants.

Throughout its operation the G7/G8 has intensified cooperation with international organizations ${ }^{9}$, affecting the programs and decisions taken by the UN Security Council, IMF, WB, WTO, OECD and many others responsible for global political, economic, military, humanitarian, and ecological security. It is worth bearing in mind that the decisions taken by the leaders are a result of immense and intensive work by diplomats and experts (called Sherpas), who work year-round before and after each summit. In order to increase the efficiency of the implementation of new solutions, in addition to the leaders' summits, meetings at the ministerial level were organized ${ }^{10}$. As another element of the G7/G8 one should consider activities of special teams, appointed to undertake special tasks. These working groups generally focus on a detailed examination of certain topics and measure the effectiveness of the implementation of specific decisions or programs. Expert groups determine the possibilities for financing projects and help shape legislative initiatives taken by individual countries in order to coordinate policy ${ }^{11}$.

8 R. Matera, Droga Rosji do pełnego uczestnictwa w systemie G8. Perspektywy rozszerzenia ugrupowania [w:] Rosja, Unia Europejska, Stany Zjednoczone - współpraca czy konfrontacja?, red. M. Pietrasiak, M. Rączkiewicz, Piotrków Trybunalski 2009, s. 137-151.

9 The leaders of the G7 back in 1977 emphasized that the global economy should be viewed more broadly than just from the perspective of cooperation between governments, and should also take into account the strengthening of international organizations (Declaration: Downing Street Summit Conference, May 8, 1977, www.g7.utoronto.ca [12.11.2016]).

${ }^{10}$ C. Budd, G8 Summits and Their Preparation [w:] N. Bayne, S. Woolcock, The New Economic Diplomacy. Decision-Making and Negotiation in International Economic Relations, London 2005, s. 140.

11 A. Dybczyński, Grupa Siedmiu (G-7/G-8) [w:] Organizacje w stosunkach międzynarodowych. Istota, mechanizmy działania, zasięg, red. T. Łoś-Nowak, Wrocław 2004, s. 372. 
The main document of each summit used to be an economic declaration (also called a declaration or final/summit communiqué). Separate communiqués on behalf of the G7 and G8 (the latter known as the 'Group of Eight' beginning in 1997) were issued during the period 1997-2002. The Summit in Evian, France in 2003 was the first in which all documents were signed by the eight leaders. Economic declarations, communiqués, and joint plans/programs of action included recommendations for members of the group, and they contained proposals directed to international organizations. The declarations encouraged the building of new bodies inside the G7/G8 system. But the output of the summits has also included many other documents: political declarations, special declarations on particular aspects of the world economy or the international situation, chairman's summaries, reports, and even press releases. The summit documents are the main source of the analysis of G7/G8 initiatives and the challenges undertaken in the fields of global economics and politics.

All these various documents cover a wide range of subjects: macroeconomic policy (inflation, employment, economic growth); trade and monetary system issues; new financial architectures; energy problems; North-South (including debt initiatives) and East-West relations; environmental themes; transnational questions; global political problems (e.g. terrorism); and many other regional issues (international conflicts and civil wars).

The G8 summit (now once again the G7 summit) as an institution is a place where a wide range of issues are taken up in debates (sometimes prepared by experts). However, it is difficult to make such a formula effective in all sectors or areas. A lot depends on the state which hosts a summit. This country and its representatives and experts (sherpas) prepare the schedule and agenda. Of course there can be no compromises on issues untouched by the summit, but concentrating on effectiveness of compromises reached and producing as many commitments as possible is the goal, and the number of problems to be solved is considered to be increasing in a positive direction if the total number of realized commitments are higher in each summit than in the previous meetings and consultations.

In examining the G7/G8 summits it is also worthwhile to investigate the role of particular countries in the process. There are wide differences in terms of their engagement in the execution of commitments. The highest ranking country in this regard is Canada, and Great Britain has also produced good results in this sphere, while the US, EC and Germany perform above average. The country with the lowest ranking in terms of execution of G8 recommendation is Russia. On one hand Russia enlarges the spectrum of interests of the G8 (especially with respect to international security), but in many other spheres it postpones important initiatives. At the same time it should be kept in mind that even the G7 was never a fully coherent group. Each of the states worked out its own position during the summits, which depended on each country's opportunities to act in specific spheres of international relations.

It is also crucial to answer the question whether the G7/G8 is an economic forum (as the founders planned), or rather a political forum. It is important to determine if the G7/G8 is a global forum aspiring to global governance, or rather an institution mainly focused on internal issues touching its members. In order to answer this question, the main stress in this paper is put on the numerous issues surrounding international security, and different dimensions of this are emphasized based on an analysis of the commitments made by the leaders, during the yearly summits, to resolve problems in this area. At the end of this paper I try to answer the question whether such a specific intergovernmental institution is still able to act effectively and influence the different dimensions of international security inherent in the 
new political situations, especially with respect to Russia's war-oriented foreign policy in 2014-2016.

One of the goals of this research is to evaluate the activity of the G7/G8 from the perspective of more than 30 years. According to John Kirton - the Director of G8 Research Group at University of Toronto - G8 summits can be analyzed in terms of performing the most important governance functions. He listed six major roles of the summits: domestic political; deliberative; directional; decisional; delivery; and development of global governance $^{12}$.

The 'domestic political' role reflects the prestige of participating states. The leaders are voicing national concerns and attempting to secure support for their country's policies. The 'deliberative' role underlines the meaning and importance of direct communication, which helps to foster trust and transparency. The 'directional' role affirms and adjusts standards, norms, and principles. Summits create new issues and legitimize old ones. The 'decisional' role of the summit is easy to see, thanks to the taking of specific commitments and recommendations during the debate. The decisional functions cover a wide-range of both political and economic issues, and include "money mandates" and the institutional framework. The 'delivery' role refers to the process of implementation of the commitments. And last but not least, the role of 'developing global governance' is reflected in the summits' recommendations with respect to developing a permanent capacity to implement its own commitments, and to prepare and develop new ones in selected areas. These recommendations often include instructions for international organizations, mainly those which its members can control (e.g. IMF and IBRD). These instructions can contain far-reaching reforms, and they also can initiate the system's own G8 institutions ${ }^{13}$. In this sense the G8 can act as a global manager.

Figure 1 presents a scheme of the links between the G7/G8 and international organizations. This forum has had great influence on the policies, programs and decisions of UN bodies (from the Security Council to many particular agencies). as well as the IMF, IBRD, WTO, OECD and many other institutions. The simplified scheme shows how broad are the links between the G8 summit and other institutions, both economically and politically.

In looking at the period of G8 summits it is also worthwhile investigating the roles of the particular countries in that process. The difference in engagement in the execution of commitments is wide. The highest rank is held by Canada (66\%), while Great Britain also attained good results (65\%). The US, EC and Germany are above average, and the lowest level of the execution of G8 commitments is held by Russia. However, the process of adjustment takes place very slowly, which is quite obvious when we look into the political and economic differences between the former G7 and Russia. The leaders realize that every subsequent enlargement can reduce the effectiveness of the forum, which is why they have remained sceptical towards expansion, i.e. accepting new members. On one hand Russia enlarges the spectrum of interests of G8 (especially with respect to international security), but in many other areas it has postponed important initiatives. At the same time, as has been pointed out even the G7 was not a fully coherent group. Each of the states elaborated its own position at the summits, which depended in large part on its opportunities to act effectively in international relations. Differences even between the EU members of the G7/G8

\footnotetext{
${ }^{12}$ J. Kirton, Explaining G8 Effectiveness: A Concert of Vulnerable Equals in a Globalizing World, March 2004, G8 Research Group, Toronto 2004, http://www.g7.utoronto.ca (12.11.2016).

${ }^{13}$ Ibidem.
} 


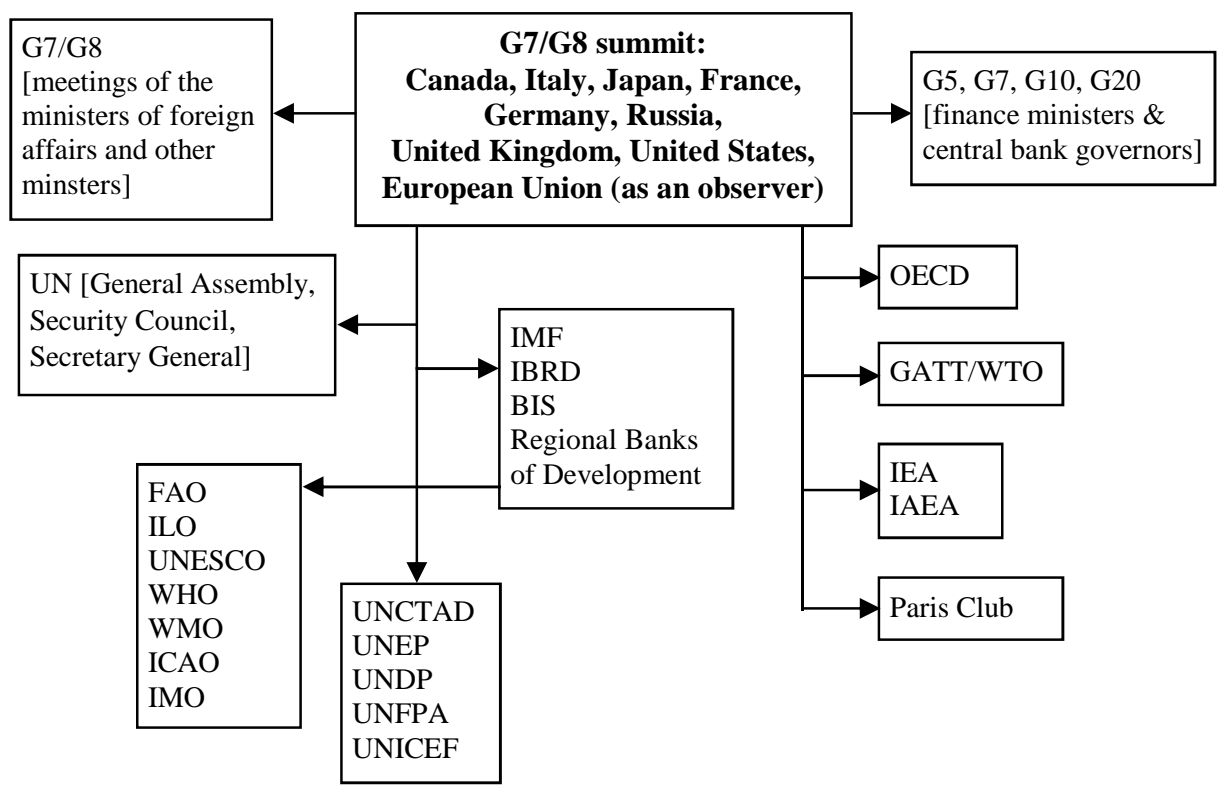

Figure 1. The G7/G8 System. Connection with international organizations

Source: R. Matera, G8 jako instytucja gospodarki światowej, Łódź 2009, s. 78.

can be seen, even though the representatives of European Communities try to develop a common position in many aspects. It is also worth underscoring that in the last six meetings the each of the states which hosted the summits has better executed their commitments. If we use this measure, the effectiveness of the G7/G8 in terms of executing its commitments should grow to an average of $77 \%$. Such a result would constitute a real global success. This means that the mobilization efforts of each host are considered as both a great challenge and motivation for the subsequent summit organizers. The hosts also feel indirectly responsible for the global situation, and in addition are pushed by world opinion ${ }^{14}$.

\section{INTEGRATION, DISINTEGRATION, AND THE POSSIBLE REINTEGRATION OF RUSSIA WITHIN THE G8}

One of the issues about which the G7 countries have had different views was "integration" with Russia. Nevertheless, even though Russia had huge economic problems and failed to comply with Western democratic standards, it still became a member of the forum. Russia's accession had mainly a political dimension. What mattered was the overall balance of profits for the West. There were many arguments in favour of Russia's membership: its natural resources, generally high (albeit outdated) degree of industrialization, and its implementation of systemic transformation. In international relations, the rapid accession of Russia to the Group of Seven was considered a major breakthrough, since for more than 70 years the Eastern Empire had been a totalitarian system, and during the cold war competed

${ }^{14}$ R. Matera, G8 jako instytucja..., s. 346-350. 
for over 40 years with the Western block. Yet it took less than a decade following the fall of the communist system for it to find its way into the group of leading industrialized democracies. It should be noted that the G7 had an indirect impact on the transformation of the largest communist juggernaut into a state with certain characteristics of democracy. However, it turned out that having the same democratic institutions did not translate into compliance with the democratic rule of law, neither in Russia internally nor in its international relations.

After more than 15 years of joint summits (counting from 1998), it was the political factor that turned out to be decisive in terms of re-evaluating Russia's membership in the elite group. Russian's violation of international agreements in 2014, together with the end of dialogue with its Western partners, led to the suspension of Russia from the G8 project. In such a situation the question arises: Should the leaders return to the proven G7 system? Since the effectiveness of the old group was higher in many areas of cooperation than that of the G8, and the differences of opinion on a number of key issues were smaller, a return to the G7 format seems to be natural. One should not bury an institution which, by creating a proven framework for informal dialogue, maintained good relations between democratic leaders of the world economy for forty years.

At the G7 meeting on 24 March 2014 in Brussels (which was scheduled to be held in Sochi in June 2014), Russia's membership in the informal institution was suspended ${ }^{15}$. In addition, at the G20 summit in Brisbane in November 2014 Russian President Vladimir Putin left the meeting early after a series of individual confrontations with Western leaders, who publicly condemned him for destabilizing the situation in Ukraine ${ }^{16}$.

Particularly significant in this regard is the position of the EU powers - Great Britain, Germany, and France. At the G7 meeting which took place on 6-7 June 2015 in Elmau in Germany, the leaders all declared that they would maintain sanctions and even escalate them if necessary. Angela Merkel made it clear that "the conflict in Ukraine can be solved only by political means, on the basis of the peace agreements signed in February in Minsk"17 a statement which is consistent with the position taken by the US administration. The leaders said that the return of Vladimir Putin to their group is currently impossible.

Also, at the Japanese summit in Shimei (Ise-Shima) on 26-27 May 2016, the G7 leaders reaffirmed their sanctions against Russia. As the result of the annexation of Crimea and Russian support for the pro-Russian rebels in eastern Ukraine, Russia is not only excluded from the G8, but also certain financial operations have been blocked and loans to Russian banks suspended, as well as introducing a ban on the sale of some advanced technologies to Russian companies. The G7 leaders declared that "We reaffirm that the duration of sanctions is clearly linked to Russia's complete implementation of the Minsk agreements and respect for Ukraine's sovereignty. Sanctions can be rolled back when Russia meets these commitments"18. Putin's policy and the behaviour of Russian rebels did not convince any

15 G7 Leaders' Communiqué on Foreign Policy Brussels, June 4, 2014, http://www.g8.utoronto.ca/ summit/2014brussels/foreign-policy.html (21.04.2015).

16 Vladimir Putin leaves G20 after leaders line up to browbeat him over Ukraine, https://www. theguardian.com/world/2014/nov/16/vladimir-putin-leaves-g20 (14.06.2015).

17 Państwa G7 groża Rosji dalszymi sankcjami, http://wyborcza.pl/1,75477,18080320,Panstwa_G7_groza_Rosji_dalszymi_sankcjami.html\#ixzz3cV9BBVXo (14.06.2016).

18 G7 Ise-Shima Leaders' Declaration, G7 Ise-Shima Summit, 26-27 May 2016, https://www. whitehouse.gov/the-press-office/2016/05/27/g7-ise-shima-leaders-declaration (12.11.2016). 
of the leaders. The sanctions were supported by all EU countries, the USA, Canada and Japan $^{19}$.

Jean Monnet wrote that "nothing can be achieved without people, but nothing becomes permanent without institutions" ${ }^{20}$. He saw a close correlation between people and institutions. People create institutions; they change and guide them. Human activity, however, is short-lived, while an institution may last longer and its long-term impact on society, the state, and the international environment is generally stronger. At the same time, it is people who take responsibility for the functioning of institutions. In the case of the G7/G8 summits, the influence of leaders on their form and results is greater than in the case of traditional, formalized organizations. With so few participants, it is more difficult for them to blame each other for any failure. These are the heads of governments, who accept compromise on key world issues and cannot evade responsibility for the fate of the world. They can also set higher standards for the other participants in international relations. Thus it was not Russia that did not fit the G8, but its leader Vladimir Putin who, by his decisions of March 2014, paved the way for Russia's exclusion from the Group. At the same time however, while the G8 in its current composition has become useless as an institution working for world security, this does not stop the further involvement of the G7.

\section{REFERENCES}

[1] Budd C., G8 Summits and Their Preparation [w:] N. Bayne, S. Woolcock, The New Economic Diplomacy. Decision-Making and Negotiation in International Economic Relations, London 2005.

[2] Declaration: Downing Street Summit Conference, May 8, 1977, www.g7.utoronto.ca (12.11.2016).

[3] Dybczyński A., Grupa Siedmiu (G-7/G-8) [w:] Organizacje w stosunkach międzynarodowych. Istota, mechanizmy działania, zasiegg, red. T. Łoś-Nowak, Wrocław 2004.

[4] G7 Ise-Shima Leaders' Declaration, G7 Ise-Shima Summit, 26-27 May 2016 https://www. whitehouse.gov/the-press-office/2016/05/27/g7-ise-shima-leaders-declaration (12.11.2016).

[5] G7 Leaders' Communiqué on Foreign Policy Brussels, June 4, 2014, http://www. g8.utoronto.ca/summit/2014brussels/foreign-policy.html (21.04.2015).

[6] Hajnal P., The G-7 Summit and Its Documents, "Government Information in Canada" [Electronic Journal], 1995, no 3.3.

[7] Kirton J., Explaining G8 Effectiveness: A Concert of Vulnerable Equals in a Globalizing World, March 2004, G8 Research Group, Toronto 2004, http://www.g7.utoronto.ca (12.11.2016).

[8] Lin M., A. Morson, Muravska J., Verli D., Russia and the G8. An Overview of Russia,s Integration into the G8, G8 Research Group, Toronto 2006, http://www.g7.utoronto.ca (12.11.2016).

[9] Matera P., Koordynacja sankcji Stanów Zjednoczonych i Unii Europejskiej wobec Rosji, „Polityka i Społeczeństwo” 2016, nr 2(14), DOI: 10.15584/polispol.2016.2.3.

${ }^{19}$ Read more: P. Matera, Koordynacja sankcji Stanów Zjednoczonych i Unii Europejskiej wobec Rosji, „Polityka i Społeczeństwo” 2016, nr 2(14), DOI: 10.15584/polispol.2016.2.3; S. Secrieru, Russia under Sanctions: Assessing the Damage, Scrutinizing Adaptation and Evasion, Warszawa 2015.

20 J. Monnet, Memoirs, New York 1978. 
[10] Matera R., Droga Rosji do petnego uczestnictwa w systemie G8. Perspektywy rozszerzenia ugrupowania [w:] Rosja, Unia Europejska, Stany Zjednoczone - wspótpraca czy konfrontacja?, red. M. Pietrasiak, M. Rączkiewicz, Piotrków Trybunalski 2009.

[11] Matera R., G8 jako instytucja gospodarki światowej, Łódź 2009.

[12] Monnet J., Memoirs, New York 1978.

[13] Official Website of the Prime Minister of Canada, http://www.pm.gc.ca/eng/news /2014/03/02/statement-g-7-nations (14.06.2016).

[14] Państwa G7 groża Rosji dalszymi sankcjami, http://wycza.pl/1,75477,18080320, Panstwa_G7_groza_Rosji_dalszymi_sankcjami.html\#ixzz3cV9BBVXo (14.06.2016).

[15] PAP, http://wiadomosci.gazeta.pl (14.06.2016).

[16] Press Conference of Mr. François Mitterrand, President of the French Republic, on the Conclusion of the Fifteenth Summit of Industrialized Countries, July 16, 1989, www.g7.utoronto.ca (10.09.2010).

[17] Secrieru S., Russia under Sanctions: Assessing the Damage, Scrutinizing Adaptation and Evasion, PISM, Warszawa 2015.

[18] Vladimir Putin leaves G20 after leaders line up to browbeat him over Ukraine, https://www.theguardian.com/world/2014/nov/16/vladimir-putin-leaves-g20 (14.06.2015).

\title{
G8 - ZMIERZCH CZY UPADEK? OD ZIMNEJ WOJNY DO ZIMNEJ WOJNY. KRÓTKA HISTORIA ROSYJSKIEGO UCZESTNICTWA W GRUPIE GLÓWNYCH DEMOKRACJI PRZEMYSŁOWYCH
}

\begin{abstract}
W wyniku rosyjskiej polityki na Ukrainie i po aneksji Krymu przywódcy G7 zdecydowali 25 marca 2014 r. na szczycie nuklearnym w Hadze, że zamiast spotkania G8 planowanego w Soczi w czerwcu 2014 r. odbędzie się szczyt przywódców G7 w Brukseli. Te wydarzenia dotyczące działania Grupy głównych demokracji przemysłowych zostały m.in. uwzględnione w prezentowanym artykule. Do podstawowych jego celów należały: krótkie przedstawienie przyczyn ustanowienia G7 i G8; syntetyczne wskazanie na różnorodne problemy omawiane na dorocznych szczytach; podkreślenie specyfiki stosunków G7/G8 z organizacjami międzynarodowymi oraz ocena efektywności poszczególnych państw Grupy w realizacji decyzji podejmowanych na szczytach. Na końcu artykułu podjęta została próba odpowiedzi na pytanie, czy w nowej politycznej sytuacji, ta instytucja międzynarodowa (funkcjonująca aktualnie bez Rosji) może nadal działać aktywnie na rzecz globalnego bezpieczeństwa, zwłaszcza śledząc działania rosyjskiej polityki zagranicznej w latach 2014-2016. Ważnym celem badania była również ocena aktywności całej G7 i G8 z perspektywy ponad 30 lat.
\end{abstract}

Słowa kluczowe: G7, G8, geneza, system, instytucje międzynarodowe, relacje z Rosją.

DOI:10.7862/rz.2017.hss.29

Przestano do redakcji: luty $2017 \mathrm{r}$.

Przyjęto do druku: czerwiec 2017 r. 